\title{
Community Forestry and Local Development: Experiences from the Koshi Hills of Nepal
}

\author{
Neeraj Chapagain* and Mani Ram Banjade** \\ *Livelihood \& Forestry Programme (LFP), Nepal \\ **ForestAction Nepal \\ Corresponding author: n-chapagain@Ifpeast.org.np
}

\begin{abstract}
Although community forestry is recognised as a successful programme in terms of rehabilitating forest condition, its contributions to local community development are not recognised adequately by the national policies, legislations and regulatory frameworks. Drawing on the results of a survey of 1100 Community Forest User Groups (CFUGs), a rapid social analysis of 24 CFUGs, and the review of local development practices in the Koshi Hills, this article claims that the organisational scope of CFUGs is not just limited to forestry activities but encompasses a wide range of development activities. The CFUG as a development institution provides opportunities for exercising political agency for democratic and equitable governance, and could demonstrate the innovations on poverty reduction through community forestry. This is demonstrated through a) significant CFUG investment in livelihoods/development sector outside of forest development, b) wide-ranging collaborative actions between CFUGs and nonforestry stakeholders, and c) innovative initiatives of poverty reduction, and inclusive and deliberative governance. The findings present a clear opportunity for development agencies and policy makers to promote CFUGs as the institutional platform for pro-poor local development.

Key words: community development, community forest user groups, collaboration, poverty reduction, governance
\end{abstract}

\section{INTRODUCTION}

There is a widespread appreciation that community forestry is a successful programme of Nepal in terms of rehabilitating forest condition (Branney and Yadav 1998, Gautam et al. 2003, Jackson et al. 1998, Karna et al. 2004, Pokharel et al. 2007, Yadav et al. 2003). In addition, contribution of community forestry in community development is also highlighted increasingly in the later phase of community forestry (Dev et al. 2004, Pokharel and Nurse 2004). However, the contribution of CF in local development has not been adequately recognised in the national policy discourses. The researches have created some awareness at the professional and practitioners' level but could not provide a comprehensive analysis at the larger scale to make it plausible enough to influence policies. Particularly, the development agencies often narrowly define Community Forest User Group's (CFUG's) role only for forest management and utilisation. Unlike this definition, CFUGs are autonomous and perpetual institutions with rights to mobilise all type of resources for the wellbeing of communities at large. In practice, these CFUGs are conducting a range of community development activities and, in some cases, they have put more emphasis on local infrastructure development than the management of forests (Banjade and Paudel 2008, McDougall et al. 2008). While the Forest Act has kept the scope of CFUG broad and open, the guidelines and directives issued by the government forestry authorities (mainly the Department of Forest) often tend to limit the CFUGs in forest management. On the other hand, CFUGs sometimes tend to put high emphasis on the local development, paying inadequate attention to the development of the forest resource itself (despite the provision of CF guideline that made it compulsory to spend at least 25 percent of CFUG income in forest development).

This article analyses the investments made by the CFUGs and reveals that CFUGs are effective institutional platforms for local development since they allocate major chunk of their income annually in local development. The paper also discusses on how and to what extent CFUGs 
collaborate with various development agencies for community development activities such as construction of school buildings, supplementing remuneration of school teachers and reading materials, construction of roads, and setting up water supply systems and irrigation canals. The paper does not analyse the forest management practices, but builds on the existing body of knowledge that CFUG management of forests has generally led to favourable outcomes on forest conservation sustainability (as outlined at the beginning of this paper).

Most of the data used in this paper are derived from secondary sources and literature reviews: annual reports from the respective CFUGs, annual monitoring study and categorisation study done by Livelihoods and Forestry Programme (LFP) of Department for International Development (DFID). The studies were conducted in more than 1,100 CFUGs in the four districts of the Koshi Hills of Nepal, i.e. Bhojpur, Sankhuwasabha, Terhathum and Dhankuta. In addition to the secondary sources, the experiences of the authors for over 12 years are a key source for qualitative information.

\section{BACKGROUND}

People living in the remote areas of Nepal are largely deprived of the basic support services from the government. Moreover, the financial support mechanism to the rural and forest dependent communities are very poor, or, in many places, do not exist. Very limited budget is allocated by the government in these areas. Similarly, there exist very limited access of credit facilities through the formal channels such as Banks and financial institutions, and, therefore, local rich people lend money in high interest rates to the poor. In the condition of limited support services and the budget, forest is perhaps the potential resource for local development and increasing income if the access of local people to the forests is ensured (KC and Khatri 2008).

Incidence of poverty is extremely high in the rural areas of Nepal'. Since the poor people of these areas have very limited or low resources on their own, they are largely relying on community or government managed forests for their livelihoods. Moreover, Livelihoods of majority of the rural people in Nepal depend heavily on subsistence oriented agriculture for which forest resources provide the necessary goods and services. In addition, forests also provide employment opportunities through small scale forest enterprises at their doorsteps.

Community forestry provides additional institutional platform for mobilising financial and social capitals and hence provides safety nets for the livelihoods of the poor and disadvantaged groups. In the recent years, CFUG has also mobilised its institutional capital to develop community infrastructure such as schools and roads. In this way, the community based forest management approach has emerged as a successful program to improve the forest condition and livelihoods of people (Agrawal and Ostrom 2001, Chakraborty 2001, Koirala et al. 2008, Webb and Gautam 2001).

Though Nepal has started the community forestry program since 1978, the speed of handing over forests to the local people became higher after the promulgation of Forest Act (1993) and Forest Regulation (1995). Currently, a total of 1.6 million households (35 percent of total population) organised in over 14000 CFUGs are managing 1.2 million hectares of forest (25 percent of total forest land) of Nepal. The Forest Act 1993 and the Forest Regulation 1995 provide strong legislative back up for community forestry in Nepal. The Act and regulations define community forest user groups as self-sustained and perpetual entities. The regulatory provisions authorise CFUGs to formulate their own rules, enforce and sanction as appropriate. The constitution of a CFUG is a key regulatory document that defines decision making and benefit sharing mechanisms within the CFUG as well as rights and responsibilities of different user members and forums. Within the legal framework defined by the rules, the CFUGs are holding regular meetings, preparing and amending rules, allocating annual budget for different local development initiatives. Learning from the experiences of CFUGs has also shown 
the promise to address the issues of inclusion and equity including support to poverty reduction through community forestry. Some innovative CFUGs are already supporting poverty reduction and marginalised group focused activities. For poverty reduction activities, the CFUGs identify the poorest households through well-being ranking based on the locally developed criteria. To institutionalise the experience of CFUGs in poverty reduction, government has made the well-being ranking a mandatory process (second revision of CF guidelines 2000) while preparing CFUG constitution. So, the well-being ranking has become a first step towards pro-poor activities, equitable representation and benefit sharing. As a result of the provisions in the guidelines, as well as the continuous advocacy from the CFUG networks, Non-governmental Organisations (NGOs), donors and government agencies, CFUGs are giving priority to the poor and excluded groups during benefit sharing, supporting their income generation activities, providing access to leadership and decisionmaking forum, etc.

The CFUGs own natural resource base, i.e. the forest, and are legally recognised autonomous institutions to mobilise resources. Their activities of community development are highly diverse and accommodative. For example, Pokharel (2005) has shown that CFUGs are performing the responsibilities of as much as 16 line ministries of the government of Nepal including Ministry of Forest and Soil Conservation, local development, law and justice, finance, home, and others. Therefore, CFUGs should not be perceived narrowly for 'forestry' and 'forest products', and their practice of wider democratic governance and community development should be adequately recognised.

As stated earlier, most rural people in Nepal depend on traditional agriculture and livestock for their livelihoods. Forest for them is a major component that contributes by providing income, construction materials, and animal feed. Integration of agriculture with forestry is the reason why we observed indigenous mode of forest management in remote rural areas, an attribute for strong realization for community based forest management in the past. Since the CFUGs are legally recognised autonomous institutions, they can pull the diverse resources from external sources such as government, nongovernment and bilateral organisations. In Nepalese context, the CFUGs have been pulling these resources to support their larger community development initiatives. The CFUGs also offer an entry point and vantage for wide range of service providers who would like to work within the communities. In this way, the CF Program in Nepal has proved to be a constructive partnership in forestry between farmers and the government.

At local level, the CFUGs have shown a great promise through annual investments and participation in forest conservation and development activities. The CFUGs also have shown their potentials for institutional and technical innovation for poverty reduction, equitable benefit sharing, and inclusive and democratic governance. Despite the contribution of CFUGs in resource management, community development, livelihoods enhancement and poverty reduction, there is still little appreciation of such significant development contribution and potentials by government and other development agencies. For example, it has become a customary practice of development agencies to form their own local institutions to implement their development activities and they rarely consult existing institutions like CFUGs. Though District Forest Office (DFO) and District Soil Conservation Office (DISCO) are two government offices meant for similar role of conservation and development and are the components of the same ministry, there is still lack of coordination and collaboration. For the external development agencies working for community development, it would be more effective and efficient to work with CFUGs rather than investing a lot of time and resources in creating new institutions. Since most of the members of the communities are organised within CFUGs, creating several institutions 
means allocating extra responsibility to the same sets of people and wasting their valuable time in coordination and institutionalisation processes.

\section{OVERVIEW OF THE KOSHI HILLS - FORESTS, COMMUNITIES AND PARTNERSHIPS}

The Koshi Hills includes four districts of eastern Nepal viz. Sankhuwasabha, Bhojpur, Terhathum and Dhankuta where, the LFP works. It has been working since April 2001, building upon the experiences and lessons learnt from the Nepal UK Community Forestry Programme, which was implemented in the seven hills of Nepal (east and west) from 1993 to 2001.

A glimpse of total area, forest area, potential community forest area and handed-over community forest area in the Koshi Hills is given in the Figure 1 below. In the Koshi Hills, altogether 1396 CFUGs have been formed until July 2008. Likewise, more than 85 percent of the total households of these districts are included within these CFUGs and are managing 82 percent of the total forest area. Out of the total households involved in the CFUGs, about 49 percent of them are categorised relatively as poor based on participatory well-being criteria.
Regarding the ethnic composition, majority of them are from disadvantaged groups (58 percent) which include 9 percent from dalit community. The categorisation study shows that majority of the CFUGs (i.e. 61 percent) are found in active/moderate categories when assessed in terms of resource management, institutional development, social inclusion and access to livelihoods opportunities. Likewise, 25 percent, 47 percent and 28 percent CFUGs are categorised in active, moderate and less active categories respectively in terms of forest management.

As the existing achievements made by the CFUGs in terms of contribution in wider development activities are encouraging, more possibilities are seen from the plans for 2008/og. These plans anticipate effective, efficient and creative environment of collaboration with other agencies to implement community development plans of these CFUGs. The CFUGs are optimistic for the partnership and highlight the possibility that the partnership with different stakeholders can foster mutual understanding, increase acceptance of community, maximise the effectiveness and leverage of resources, and avoid the duplication of programme within same geographical areas.

Figure 1: Status of community forestry in the Koshi Hill districts

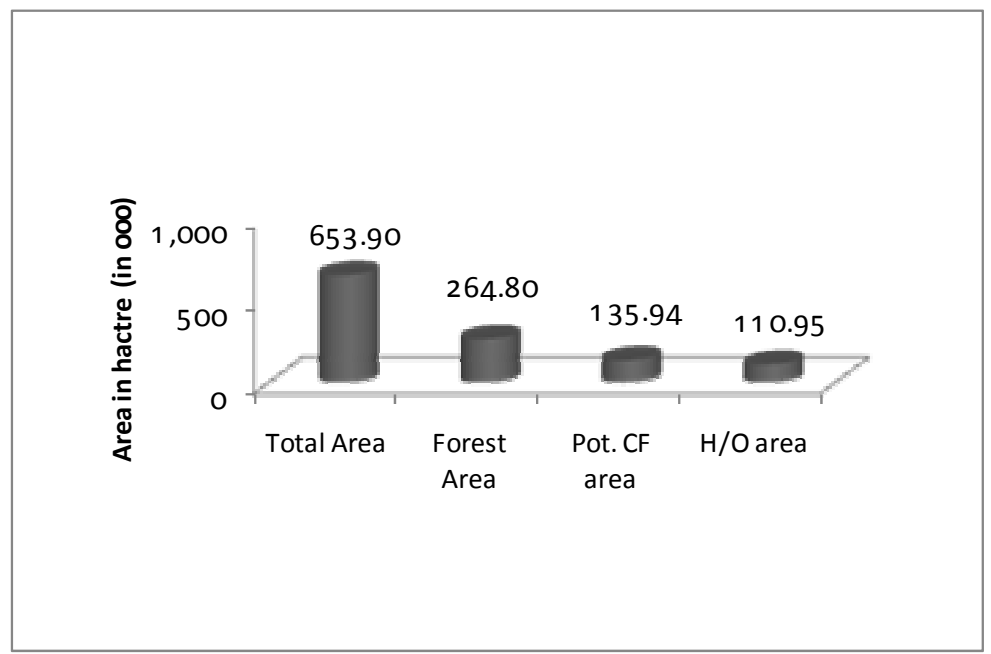

Note: Pot. $=$ Potential, $\mathrm{H} / \mathrm{O}=$ Handed over 


\section{FINDINGS}

Increased Growing Stock and Production within Community Forests

In the context of the Koshi Hills, the community forestry programme so far has resulted increased growing stock and harvestable amount of forest products. An earlier study in four eastern hill districts showed that the total number of stems per hectare has increased by 51 percent and the basal area by 29 percent (Branney and Yadav 1998). When we analyse the recent data from the Koshi Hills, 51 percent of the CFUGs are managing their CFs actively (CFUG categorisation study 2006). More than
93 percent CFUGs have reported that the condition of forest in terms of growing stock, forest cover, and availability of forest products and status of biodiversity has significantly improved after handing over of the forests to the communities (Table 1). Reports from other areas also have shown the similar improvements. For example, in the Kabhre and Sindhupalchok districts of central Nepal, a study found that shrub land and grassland have been converted into productive forests, and, - thus, the productive forest area has increased from 7,677 hectares to 9,678 hectares (Jackson et al. 1998).

Table 1: Changes in Forest Condition Over 7 Years as per Operational Plan (same CFs handed over until 2001)

\begin{tabular}{|l|r|r|r|r|}
\hline Forest condition & \multicolumn{2}{|c|}{2001} & $\mathbf{2 0 0 8}$ & Percent \\
\hline Good & Number of CFs & Percent & Number of CFs & $67 \%$ \\
\hline Average & 679 & $60 \%$ & 760 & $29 \%$ \\
\hline Degraded & 405 & $36 \%$ & 326 & $4 \%$ \\
\hline Total & 51 & $4 \%$ & 49 & $100 \%$ \\
\hline
\end{tabular}

The result of regular monitoring study shows that the barren and degraded CF lands have also been re-vegetated through plantation and natural regeneration. As a result of community efforts, more than two-third (67 percent) of CFs fall under the good category while more than one-forth (29 percent) and about 4 percent CFs fall in the average and degraded categories respectively (Table 1). Similarly, the recent resource assessment shows that 30 percent biomass has increased over the period of 14 years in the Koshi Hills.

The area is also potential in terms of Nontimber Forest Products (NTFPs) promotion. More than 60 percent CFs are found potential for the promotion of NTFPs.

More than 60 percent CFUGs are implementing specified silvicultural operations as planned in the CFUG operational plans. About 27 percent CFUGs have received technical support from external agencies while implementing such operations. Additionally, as a result of partnership, CFUGs have planted about 0.6 million seedlings of different NTFP/fodder species. Similarly, they are producing more than 100 thousand seedlings every year. Although, DFO is exclusively responsible to deliver the technical support to the CFUGs, local resource persons (LRP Technical) trained and mentored through a collaborative effort between DFO, Federation of Community Forest Users Nepal (FECOFUN) and other line agencies have played a vital role to enhance technical skills of the forest users.

\section{Income of the Community Forest User Groups Increased from the Sale of Forest Products}

Since Community Forest User Groups (CFUGs) are managing their forests actively, the income from the forest products is also increasing significantly over a period of time. This has been the result of devolution of power of forest resource management to the local forest users. 
For example, in 2002, annual income of the Department of Forest was Nepalese Rupees (NRs) 550 million $^{2}$ and total budget was NRs 680 million, but the Community Forestry which covers only 25 percent of total forest area, had generated an income of about 740 million, which is higher than the annual budget of the Department of Forest and is almost 42 percent of the annual budget of the Ministry of Forest and Soil Conservation (Kanel and Niraula 2004, Koirala et al. 2008). From the study of the income of the CFUGs from the Koshi Hills alone we found that in addition to improving the forest condition the CFUGs have been able to raise income through forest products sale.

Similarly, the users are contributing their significant time in the forest development activities. For example, they spend more than 2.5 million person days of voluntary labor in forest-related activities every year. The value of this voluntary labor contribution is about 164 million rupees calculated using a conservative value for opportunity cost of 65 rupees per person per day (Kanel and Niraula 2004). The recent monitoring study (2007) shows that the total income per year of CFUG is found significant (Table 2).

Table 2: Annual Income and Expenditure Status 2006/07

\begin{tabular}{|l|r|r|}
\hline Total Income $^{\mathbf{3}}$ & $\mathbf{1 0 0 \%}$ \\
\hline Brought forward from previous FY & $\mathbf{5 7 , 9 2 9 , 2 0 8}$ & $\mathbf{4 5 \%}$ \\
\hline Forest resources & $14,378,858$ & $25 \%$ \\
\hline Fees, fine, interest, etc. & $3,769,927$ & $7 \%$ \\
\hline External funding - LFP & $3,307,294$ & $6 \%$ \\
\hline External funding - Others & $10,646,796$ & $18 \%$ \\
\hline Total Expenditure & $30,635,148$ & $\mathbf{1 0 0} \%$ \\
\hline Forest development & $4,883,822$ & $16 \%$ \\
\hline Targeted Activities (to the poor and excluded) & $8,498,515$ & $28 \%$ \\
\hline Institutional Development & $3,039,807$ & $10 \%$ \\
\hline Community Development & $14,213,005$ & $46 \%$ \\
\hline Balance to the next year & $27,294,061$ & $47 \%$ \\
\hline
\end{tabular}

Community Forest User Groups as an Institution for Community Development and Societal Change

\section{Community development has been the focus}

In eastern Nepal, community forest user groups have been able to invest US\$ 327,000 generated by the sustainable use of forests over ten years in formal school education, informal literacy programs for women and the poor, and scholarship for poor students. Some CFUGs have contributed to construction and maintenance of roads, schools, irrigation canals, health posts, etc. which has caused several direct and indirect positive impacts upon livelihoods of the people living in the area. Furthermore, CF has brought supportive influences on agriculture production, income and employment generation, biodiversity conservation, democratic governance, social unity and literacy in society. In this way, CF has brought a change of great socio-economic 
significance in rural society (Branney and Yadav 1998, Malla 2000, Pokharel et al. 2005). This study of over 1100 CFUGs of the Koshi Hills shows that CFUGs have been conducting a wide range of community development activities (Box 1).

\section{Box 1: A glimpse of ongoing CFUG activities in the Koshi Hills for the fiscal year 2007/08}

- $30 \%$ of the CFUGs implement silvicultural treatment in line with the block management system. Likewise $11 \%$ CFUGs are intensively involved in the plantation of barren land,

- Altogether 8029 households (HHs) will be benefited from the different IGA schemes through the revolving fund in 426 CFUGs,

- 230 ha of land will be allocated within the CFs to 767 poor households for conducting IGAs (67 CFUGs),

- In addition to the revolving fund and CF land allocation, additional 319 poor households will be benefited from different IGAs (26 CFUGs),

- 23 CFUGs implement health and sanitation related activities where 177 households will be directly benefited,

- Likewise, 26 CFUGs will construct and distribute a total of 177 improved cooking stoves where $82 \%$ of the recipients will be from the poor households,

- To enhance capacity of the poor users in order to enhance sustainable livelihoods, a total of 130 events are planned where altogether 1011 poor households can benefit from self employment opportunities,

- Altogether 167 CFUGs are implementing drinking water schemes, which will benefit a total of 12480 households where $68 \%$ are from the poor community,

- It is expected to maintain and establish $22 \mathrm{KM}$ irrigation canal where 7217 households will be directly benefited where $65 \%$ of them will be from the poor categories (41 CFUGs),

- Altogether $136.5 \mathrm{KM}$ trail road will be maintained, which will help ease the access to the market (297 CFUGs),

- 67 CFUGs support schools by providing remuneration of school teachers,

- 907 households from 10 CFUGs are benefited from electrification where $52 \% \mathrm{HHs}$ are from the poor categories,

- 5 CFUGs are constructing 15 wooden bridges,

- 30 CFUGs are constructing new office buildings, a step towards institutional development, and

- 5 CFUGs have planned some ecotourism promotion activities (developing picnic spots, etc.).

\section{Community forest user groups increasingly addressing poverty reduction and inclusion agendas}

In addition to the subsistence supply of forests, the CFUGs in the proposed plans (FY 2008/9) have provisions to directly support more than 33 percent of the total households during the fiscal year (both the poor and non-poor). Out of the total households benefited to date, 41 percent of them were benefited from Forest Development (FD). Similarly, 75 percent, 12 percent and 10 percent of the households got the benefits from Community Development (CD), Skills/Institutional Development (ID) and Income Generating Activities (IGA) respectively. This does not include the benefits received from the use of revolving fund for IGA. The finding shows that the CFUG's intervention is being intensively focussed towards targeted activities while CFUGs are able to cover more than onethird of the poor households annually through different opportunities (CFUG plan 2007/08).

At the end of the fiscal year 2008/9 the CFUG plans envisage that more than 40,000 members including $27 \%$ women and $55 \%$ poor will be involved in forest development activities. Likewise, about 75,000 users will be involved as paid labor of which more than 70 percent are from the poor and one-third from women. So far, already women representation in the decision making forums is 35 percent in the Koshi Hills. 
The various monitoring studies show that the CFUGs are able to contribute through their income to at least 67 percent of the total households by engaging them in several community development and livelihoods focus activities. Income generating activities are provided to at least 17 percent of the poor users annually. Particularly in the hills, most of the households around a CF are included within the respective CFUGs, thus creating a platform for interest negotiation and political engagement for all people living within a geographical constituency.

At large, the CFUGs are providing public services. For example, when there were no political institutions in the rural areas for democratic deliberations during the time of insurgency in Nepal (1995-2005), the CFUGs served the purpose (Banjade and Timsina 2005). In the context of the Koshi Hills, more than 85 percent of the total households are involved in CFUGs as members. So far, through direct financial intervention, CFUGs in the Koshi Hills have provided support in income generating activities to more than 20,000 households aiming to enhance their economic conditions. The data shows that the emphasis and priority goes to the dalit community as more than 80 percent of the dalits fall below the poverty line. Likewise more than 3,500 and 14,000 poor households have been benefitted from skill development trainings and infrastructure support respectively.

Reflecting on the earlier community development activities where some CFUGs invested their income in economically unproductive areas such as temple, the LFP facilitated to shift the focus towards livelihoods enhancement particularly the activities targeted to the poor and most marginalised groups. That is why LFP introduced the concept of 'revolving fund' in the area. The fund is exclusively targeted for the economic upliftment of the poor and marginalised members of the CFUGs. Initially, LFP, through its partners, facilitated to establish a basket fund and provided some initial seed money so that the CFUGs so supported could direct more investments in the areas that generate income directly to the poor individuals, a shift of investment focus from physical infrastructure development. The recent monitoring study (2008) shows that out of the directly benefited 13,000 households, 20 percent of the poor households were additionally benefited after the introduction of revolving fund over the last five years (Table 3).

Table 3: Total Benefits to Households from IGAs and Revolving Fund

\begin{tabular}{|l|l|}
\hline From Direct financial intervention (HH) & 13241 \\
\hline After revolving fund (HH) & 10,242 \\
\hline Total benefited from IGA (HH) & 23,483 \\
\hline Total poor HHs (from well-being ranking) & 49,605 \\
\hline \% poor HH benefitted from IGA & $20 \%$ \\
\hline
\end{tabular}

In the Koshi Hills hundreds of CFUGs have allocated certain portion of their CF land to the identified poor as a means of sustainable income for them. About 600 CFUGs (i.e. 43 percent of the total CFUGs) are found potential to allocate CF land to the poor users, of which 46 percent CFUGs have allocated 336 hectares of land to more than 2200 poor households for different income generating activities aiming to enhance their sustainable income. As observed during the field monitoring and CFUGs' progress reports, it clearly shows that such initiatives have been contributing to boost up their self reliance in terms of their livelihoods.

A study has been carried out in 2008 in the selected CFUGs of the Koshi Hills where the Animation Program of LFP has been launched since 2002. A total of 2700 randomly sampled households from 26 CFUGs were included in the analysis where data were collected through structured surveys, focus group discussions and reflection of the local leaders and animators. 
During the study, re-wellbeing ranking was conducted in the sampled CFUGs by using the same criteria and procedure used about five years ago. The study shows that 46 percent poor users (very poor and poor) have crossed the relative poverty line largely because of their engagement in the CFUGs who directly supported their livelihoods improvement related activities and capacity building events. Likewise, 35 percent of the very poor households have moved to the poor category, a step up to the ladder. The following Table 4 is the summary of the analysis where status of well-being shift has been included.

Table 4: A Glimpse of Changed Well-being Status

\begin{tabular}{|l|l|l|l|l|l|l|l|l|l|}
\hline \multirow{2}{*}{ Caste } & \multicolumn{2}{|l}{ No change } & \multicolumn{1}{|c|}{ Change (+) } & \multicolumn{3}{l|}{ Change (-) } \\
\hline Valit & $58 \%$ & $43 \%$ & $100 \%$ & $29 \%$ & $13 \%$ & $51 \%$ & $6 \%$ & $0 \%$ & $0 \%$ \\
\hline JJ & $53 \%$ & $67 \%$ & $100 \%$ & $36 \%$ & $11 \%$ & $32 \%$ & $1 \%$ & $0 \%$ & $0 \%$ \\
\hline AC & $55 \%$ & $59 \%$ & $100 \%$ & $36 \%$ & $7 \%$ & $39 \%$ & $1 \%$ & $0 \%$ & $0 \%$ \\
\hline Total & $56 \%$ & $61 \%$ & $100 \%$ & $35 \%$ & $9 \%$ & $37 \%$ & $1 \%$ & $0 \%$ & $0 \%$ \\
\hline
\end{tabular}

$\mathrm{VP}=$ Very poor, $\mathrm{P}=$ Poor, Oth=Others

Community Forest User Groups have generated employment opportunities

In reference to the Koshi Hills, CFUGs have generated an employment of about 150,000 person days per year. In addition, CFUGs are paying to about 200 teachers per year but surprisingly the records of the CFUG contribution is not maintained even in the District Education Office.
The key areas where employment has been generated by the CFUGs include: forest management and harvesting operations, community development, office management, payments to school teachers, forest based enterprises, etc. (Table 5). From the gender analysis of the employment we can see that women are getting one-third of the employment hitherto generated. While women are more in office management related jobs, they were least involved as teachers.

Table 5: Annual Employment Opportunity in CF (24 days = 1 month)

\begin{tabular}{|c|c|c|c|c|c|c|c|c|c|c|}
\hline \multirow[t]{2}{*}{ Area } & \multicolumn{2}{|c|}{ CFUG } & \multirow[t]{2}{*}{ Female } & \multirow[t]{2}{*}{ Male } & \multirow[t]{2}{*}{ Total } & \multirow{2}{*}{$\begin{array}{l}\text { P.days/ } \\
\text { CFUG }\end{array}$} & \multicolumn{4}{|c|}{ Person } \\
\hline & & & & & & & $\begin{array}{c}1 \\
\text { Month }\end{array}$ & $\begin{array}{c}3 \\
\text { Month }\end{array}$ & $\begin{array}{c}6 \\
\text { Month }\end{array}$ & $\begin{array}{c}9 \\
\text { Month }\end{array}$ \\
\hline $\begin{array}{l}\text { Forest } \\
\text { management }\end{array}$ & 510 & $40 \%$ & 19,294 & 44,594 & 63,888 & 125.19 & 2,662 & 887 & 444 & 296 \\
\hline $\begin{array}{l}\text { Community } \\
\text { development }\end{array}$ & 340 & $27 \%$ & 3,350 & 6,061 & 9,411 & 27.66 & 392 & 131 & 65 & 44 \\
\hline $\begin{array}{l}\text { Office } \\
\text { management/ } \\
\text { office } \\
\text { secretary }\end{array}$ & 161 & $13 \%$ & 4,700 & 4,452 & 9,153 & 56.97 & 381 & 127 & 64 & 42 \\
\hline Teachers & 172 & $14 \%$ & 11,624 & 27,513 & 39,137 & 226.92 & 1,631 & 544 & 272 & 181 \\
\hline Enterprises & 95 & $7 \%$ & 5,775 & 10,161 & 15,937 & 168.64 & 664 & 221 & 111 & 74 \\
\hline Total & 256 & $20 \% *$ & 44,744 & 92,782 & 137,526 & 537.99 & 5,730 & 1,910 & 955 & 637 \\
\hline
\end{tabular}




\section{Community Forest User Groups Harnessing Expanded Collaboration Opportunities}

The Table 6 given below gives a glimpse of CFUG fund mobilised in the year 2001 and 2007. The budget of the planned activities of the CFUGs studied (carried out in 82 percent of 1160 CFUGs) for the current fiscal year (2008/9) is estimated as NRs $37,060,291$ to spend in various local development initiatives. While they have estimated an income of NRs. 327,000,00 from the CFs, they are expecting to get the rest from other sources such as support from development agencies. This is a realistic estimate looking at the previous year's figure when they could manage about NRs $32,200,000$ (about 40 percent of the total budget) from other organisations.

Table 6: Trend of CFUG Fund Mobilisation Status

\begin{tabular}{|c|c|c|c|}
\hline & 2001 & 2007 & Differences \\
\hline No. Of CFUG & 1,211 & 1061 & -150.00 \\
\hline Total income & $4,967,117.63$ & $32,102,874.55$ & $27,135,756.92$ \\
\hline Income/CFUG & $4,101.67$ & $30,257.19$ & $26,155.52$ \\
\hline Total expenditure & $3,537,797.00$ & $30,635,147.50$ & $2,709,735,0.50$ \\
\hline Expenditure/CFUG & $2,921.38$ & $28,873.84$ & $25,952.46$ \\
\hline Poor focus & $95,948.00$ & $8,498,514.50$ & $8,402,566.50$ \\
\hline Poor focus/CFUG & 79.23 & $8,009.91$ & $7,930.68$ \\
\hline Poor focus \% & $3 \%$ & $28 \%$ & $25 \%$ \\
\hline
\end{tabular}

To pull the resources from diverse sources and increase collaboration of various development agencies, an innovative concept of establishing and strengthening Forest Development Fund is also in practice in the Koshi Hills. The objective of the fund is to sustain forest and community development initiatives in future according to the need and aspirations of the users. VDCs can claim NRs 20,000 to 40,000 fund from LFP as per their collaborative efforts, i.e. based on the size of fund generated through collaboration at local level.

So far the establishment and strengthening of forest development fund as a basket funding approach in VDCs is found as an initiative to sustain their good practices and to extend an opportunity for collaboration with wide range of stakeholders at local level (Box 2). In this way, CFUGs are expanding their networks, often including stakeholders beyond the forestry sector that are working in the community development initiatives. Ultimately, a CFUG acts as an entry point for wider development. The data from the Koshi Hills shows that the CFUGs are capable of pulling a significant amount of resources from external sources. For example, the current monitoring study shows that CFUGs are getting more than 50 percent of the total investment from non-forestry sector annually. Mostly the resource available to them was to support pro-poor initiatives, income generation activities and capacity building events. 


\section{Box 2: Forest development fund (Koshi Hills)}

Basic criteria

- $\quad$ All the CFUG should be affiliated in the VDC network

- The VDC network should have inclusive decision making body.

- $\quad$ All the CFUGs affiliated in the network, should be committed to provide 5 percent of the total annual income to VDC network.

- The VDC network should receive at least some fund from VDC.

- The VDC network should prepare a fund mobilization guideline.

Note: The VDC networks are encouraged to allocate or spend their fund in OP amendment, enterprise development and IGAs, office management and management of local facilitators.

\section{DISCUSSION}

Many studies claim that conservation goals of Community Forestry (CF) have been achieved because of the devolved resource management responsibilities down to the community level (Kanel 2004, Malla 2000). This claim is rooted in the obvious changes observed in community forests because of local people's efforts in conserving forest. However, the CF programme has yet to show adequate livelihoods impacts. This paper and other earlier literature have shown the promise of CF in contributing significantly to community development and livelihoods improvement agenda.

\section{Collaboration between Community Forest User Groups and Development Agencies}

Chapagain et al. (2008) found through the use of participatory tools that if there is not any interaction between the target groups (i.e. the poor, women and marginalised) and service providers at local level the claim of achieving twin goals of conservation and poverty reduction through community forestry will be only one-third of the total possible achievements regarding the real need, demand and expectations of local people. It is, therefore, highly desirable to explore the appropriate mechanisms of enhancing collaboration, identifying relevant collaborators, and developing effective means of communication and coordination amongst them. Use of the specific tools for enhancing communication, developing common goals and mutual understanding, and promoting sharing and reflection can significantly improve partnerships among different stakeholders. When a tool called Conflict, Legitimacy, Interest and Power (CLIP) was used in the Koshi Hills (visit www.SAS-PM.com for more detail of this tools), it showed that the understanding level has increased among the partners.

From this study and authors' decade long experiences show that CFUGs can harness the benefits of collaboration. The immediate need is that policy and regulatory frameworks should provide effective strategy for increasing collaborative efforts at local level. Similarly, using the tools such as CLIP would be an effective way to enhance synergy among collaborative partners without extra efforts and resources.

\section{Compatibility between Community Forest User Groups and Government Forestry Organisations}

Despite the communities' readiness and success of resource conservation and community development through community forestry, government has not yet provided an amicable environment to promote efficiency, effectiveness and innovation at local level. When people living in remote rural areas are deprived of government services, the government forestry organisations at various levels should facilitate the processes of developing linkages of CFUGs with wider 
development agencies. Can we expect this within the current modus operandi? The question arises in the context when two government organisations, namely District Forest Office and District Soil Conservation Office, under the same ministry (Ministry of Forest and Soil Conservation) have not yet developed clear coordination and collaboration strategy to enhance same purpose and same goal. Other development organisations also do the same, i.e. they form their own institutions to implement their programs even when the beneficiaries of their initiatives and users of the CFUGs are overlapping. Although, the issue of coordination and collaboration is occasionally emphasised at higher level, concrete mechanism to foster effective local level coordination/collaboration is not yet satisfactory.

The CFUGs have been providing lots of development inputs to the areas where government is supposed to be fully responsible. They are contributing to health, education, local infrastructure development, capacity building and livelihoods improvement programs by generating their own resources through community forestry or through wider networking with other service providers. This is recognised by government personnel of Department of Forest (i.e. the line department) but has not yet sufficiently recognised by other line agencies. Therefore, program duplication, low level of community ownerships and efficiency, etc. are observed in the field.

So, this question is prominent: who is responsible to promote such initiatives of working with local institutions like CFUGs? When CFUGs have proved their capacity and have clearly shown their potential of working in diverse sectors of community development, the government should come up with clear policy and strategy to support these local initiatives. Indeed, the CFUGs should be considered as the umbrella institutions for all development initiatives. To begin with, the government should develop a clear policy and strategy to incorporate CFUGs plan into VDC/DDC aiming to make CFUG's contribution visible to nonforestry sector.

\section{Community Forest User Groups and Equitable Local Development}

Community Forest User Groups can become a conveyor for equitable local development as they have already demonstrated their capacity and willingness towards inclusion and equity. However, mainstream development practices have not fully respected the needs and concerns of local people and imposed prescriptions from outside. Consequently many development efforts failed due to the lack of ownership by the communities. In other cases, the existing policy and practices might have disempowered the communities by promoting patron-client relationships between service providers and the community members. To change the situation, the development agencies should recognise the local institutions and build their programs on the needs and demands of the communities. Community institutions like CFUGs, despite having plenty of resources, may not necessarily plan pro-poor programs and devise equitable provisions. For instance, the activities that are being implemented by CFUGs such as constructing schools, trails, irrigation channels, community buildings, temples and installing cooking stoves are found to favour wealthier households at local level (Acharya et al. 2008, Kanel 2004).

The exclusion of women in the resource management process has serious negative consequences not just for gender equity, but also for the efficient functioning and long term sustainability of these initiatives, and for women's empowerment (Agarwal 1997). Therefore, external intervention should carefully be promoted to make sure that the voices of the local poor, women and marginalised groups are considered. In the Koshi Hills, however, ethnic representation is towards proportionate level and the participation of women and the poor has followed the positive trend. The poor, women and other marginalised groups have separately organised themselves in different sub-groups. 
Formation of such sub-groups helps to get their agenda into the planning and implementation process and hence supports the inclusion and equity in the CFUGs. In the Koshi Hills, more than 25,000 different members are organised in different sub/interest groups (e.g. women, the poor, dalit, NTFP, saving/credit, etc.).

Equitable development and benefit sharing are two dimensions of social inclusion. Although equitable distribution system is still below satisfactory level the trend is quite encouraging: it is increased by double over the past 2 years, i.e. 26 percent of CFUG are practicing equitable distribution system. Therefore, all the development agencies should ensure social inclusion, poverty reduction and equity while planning and implementing development programs. A synchronised effort of different development agencies is necessary for optimum synergy and harmonisation in this regard.

Though collaborative efforts are highlighted for effective community development, there are four likely scenarios of such collaborations urging for cautious remarks on the effectiveness of collaboration: a) high effort and large outcomes, b) high effort but less outcomes, c) less effort but high outcomes, and d) less effort and less outcomes. There should not be any doubt that the collaborative model, approaching CFUG as an entry point, is one of the imperative mechanisms to enhance large outcomes with even a nominal effort.

Even where development agencies in the Koshi Hills have incorporated CFUG plan into VDC plan, Ministry of Forests and Soil Conservation and Ministry of Local Development have different planning periods which inhibit to achieve satisfactory result. Since overwhelming majority of the population is already involved in community forestry, a bottom up planning process applied in the CFUGs could satisfy the needs, expectations and demands of all the CFUG members. When local governments recognise this aspect and develop effective coordination linkages with the CFUGs and other non-forestry sectors, the resulting development outcomes will be much higher than the existing ones.

\section{CONCLUSION}

This article presented the case of CFUGs as effective institutional vehicle for local development. Although national level nonforestry sector has not fully recognised CFUGs as appropriate and effective development institutions, CFUG's achievements and progress have already proved that CFUGs are broadbased institutions that have potentialities of being the conveyors of wider development. Based on the experiences of the Koshi Hills, the paper demonstrates how CFUGs have conducted a wide range of non-forestry development activities with varying degrees of collaborative linkages with several development agencies. It is also shown that these development activities of CFUGs have led to increased livelihood opportunities to the local communities in general, and the poor and marginalised groups in particular. Given such institutional capability of the CFUGs, the development agencies have opportunities to approach CFUGs as an entry point for local development. In addition, with its three decades long experience, community forestry has proved itself to become a learning platform for wider network of development actors who have been promoting livelihoods enhancement and inclusive and equitable development.

\section{REFERENCES}

Acharya, K.P., Adhikari, J. \& Khanal, D. 2008. Forest Tenure Regimes and their Impact on Livelihoods in Nepal. Journal of Forest and livelihood, 7(1): 6-18.

Agarwal, B. 1997. Environmental Action: Gender Equity and Women's Participation. Development and Change, 1-43.

Agrawal, A. \& Ostrom, E. 2001. Collective Action, Property Rights, and Decentralization in Resource Use in India and Nepal. Politics and Society, 29: 485 .

Banjade, M.R. \& Paudel, N.S. 2008. Economic Potential of Non-timber Forest Products in 
Nepal: Myth or Reality? Journal of Forest and Livelihood, 7(1): 36-48.

Banjade, M.R. \& Timsina, N.P. 2005. Impact of Armed Conflict in Community Forestry of Nepal. ETFRN News, 43/44.

Branney, P. \& Yadav, K.P. 1998. Changes in Community Forestry Condition and Management 1994-98: Analysis of Information for the Forest Resource Assessment Study and Socio-Economic Study of the Koshi Hills. Project report G/NUKCFP/32, Kathmandu: NUKCFP.

Chakraborty, R.N. 2001. Stability and Outcomes of Common Property Institutions in Forestry: Evidence from the Terai Region of Nepal. Ecological Economics, 36: 341-353.

Chapagain, N., Chapagain, B. \& Kafle, G. 2008. Review of Poor Support Strategy and the Existing Collaboration Efforts: are the Achievements became Intact in Favour of P\&E Needs and Priorities: A Case from the East Hills of Nepal (Draft abstract).

Dev, O.P., Springate-Baginski, O. \& Karna, A.K. 2004. Understanding Livelihood Impact of Participatory Forest Management Implementation Strategy in Nepal. In: K.R. Kanel, P. Mathema, B.R. Kandel, D.R. Niraula, A.R. Sharma and M. Gautam (Eds.), Twenty Five Years of Community Forestry: Proceedings of the Fourth National Workshop on Community Forestry, Kathmandu: Community Forestry Division, Department of Forest.

Gautam, A.P., Webb, E.L., Shivakoti, G.P. \& Zoebisch M.A. 2003. Landuse Dynamics and Landscape Change Pattern in a Mountain Watershed in Nepal. Agriculture Ecosystems and Environment, 99: 83-96.

Jackson, W.J., Tamrakar, R.M., Hunt, S. \& Shepherd, K.R. 1998. Land Use Changes in Two Middle Hills Districts of Nepal. Mountain Research and Development, 18(3): 193-112.

Kanel, K.R. \& Niraula, D.R. 2004. Can Rural Livelihood be Improved in Nepal through Community Forestry? Banko Janakari, 14(1): 1924.

Kanel, K.R. 2004. Twenty Five Years of Community Forestry: Contribution to Millenium Development Goals. Fourth National Workshop on Community Forestry. Proceeding of the Fourth workshop on community Forestry, Dec. 2004. Kathmandu, Nepal: Community Forestry Division, DOF.

Karna, B.K., Gyawali, S. \& Karmacharya, M.B. 2004. Forest Condition Change: Evidence from Five Revisited Community Forests. In: K.R. Kanel, P. Mathema, B.R. Kandel, D.R. Niraula, A. R. Sharma and M. Gautam (Eds.), Twenty Five Years of Community Forestry: Proceedings of the Fourth National Workshop on Community Forestry, Kathmandu: Community Forestry Division, Department of Forest.

Koirala, R., Giri, K. \& Pokharel, B.K. 2008. Development and Status of Community Forestry Governance in Nepal.

Malla, Y.B. 2000. Impact of Community Forestry Policy on Rural Livelihoods and Food Security in Nepal. Unasylva, 51: 37.

McDougall, C., Ojha, H., Banjade, M.R., Pandit, B.H., Bhattarai, T., Maharjan, M. \& Rana, S. 2008. Forest of Learning: Experiences from Research on an Adaptive Collaborative Approach to Community Forestry in Nepal. A Synthesis of lessons from the Adaptive Collaborative Management Research Project in Nepal, 1999-2002 and 2004-2007. Indonesia: CIFOR.

Pokharel, B., Paudel, D. \& Gurung, B.D. 2005. Forests, Community based Governance and Livelihoods: Insights from Nepal-Swiss Community Forestry Project. Capitalization and Sharing of Experiences on the Interaction between Forest Policies and Land Use Pattern in Asia. ICIMOD.

Pokharel, B.K. \& Nurse, M. 2004. Forests and People's Livelihoods: Benefiting the Poor from Community Forestry. Journal of Forest and Livelihood, 4(1): 19-29.

Pokharel, B.K., Branney, P., Nurse, M. \& Malla Y.B. 2007. Community Forestry: Conserving Forests, Sustaining Livelihoods and Strengthening Democracy. Journal of Forest and Livelihood, 6(2): 8-19.

Rajendra, K.C. \& Khatri, A. 2008. Contribution of Community Forestry in Reducing Rural Poverty in Nepal: Conference on International 
Research on Food Security, Natural Resource Management and Rural Development, University of Hohenheim, October 7-9, 2008.

Webb, E.L. \& Gautam, A.P. 2001. Effects of Community Forest Management on the Structure and Diversity of a Successional
Broadleaf Forest in Nepal. International Forestry Review, 3: 146.

Yadav, N.P., Dev, O.P., Springat-Baginski, O. \& Soussan, J. 2003. Forest Management and Utilization under Community Forestry. Journal of Forest and Livelihood, 3(1): 37-50.

\footnotetext{
1 According to the World Bank's widely used poverty benchmark of US\$ 1 per capita per day, about 31 percent of Nepalese people fall under severe poverty line, it is more severe in rural areas.

21 USD $=75$ NRs (Approx.)

3 Total CFUGs included in the analysis- 1063 . Deviation of income 48,688 , maximum income $20,00,298$ and minimum income 500.
} 